\title{
Mitteilungen
}

\section{Cause or Value? \\ Problems in the Understanding of Gen 9,6a}

\author{
By Markus Zehnder \\ (Universität Basel / Ansgar Theological Seminary)
}

\section{Introduction: The Problems}

There are basically three problems in the interpretation of Gen 9,6a:

a) How is the syntactic structure of the line to be understood?

b) What is the meaning of the preposition beth attached to the second אדם ("person «)?

c) What is the likely grammatical function of the last word, ישפך' ("will / shall be shed «)?

The major options for $\mathrm{a}, \mathrm{b}$, and $\mathrm{c}$ are:

a) First option: We have to divide the line after the first ("person «), which gives a perfect chiastic structure, with three words on each side of the dividing line plus the preposition beth at the beginning of the second half. The verse reads then:/ שפך דם האדם אדם Alternatively, the second drawn to the first part, as a kind of

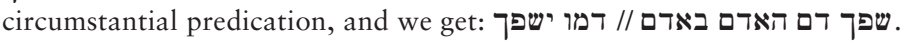

b) Possibilities of how to interpret the preposition beth depend on the syntactic understanding of the line. If we reckon - as obviously suggested by the masoretes - with a chiastic structure, that is, the variant שפך דם האדם // באדם דמו ישפך, we get the following possibilities: The first possibility is to understand באדם באו באדם as an indication of instrument or cause, »through man « or » by man « shall the murderer's blood be shed. The beth then functions as an instrumental beth or, rather, more precisely, a beth causae. The second possibility is to understand באדם as an indication of value, »for the value of a man « shall the murderer's blood be shed. The beth in this case functions as a beth pretii. ${ }^{1}$

If באדם is understood as forming the last element of the first part of the line, the following options exist: ${ }^{2}$ The first option is to interpret באדם בs an indication of location, "among man «, so that the phrase means »the one who sheds the blood of man among

1 The distinction between these two uses of the preposition beth is not always taken to be fully exclusive. C. Brockelmann, Hebräische Syntax, 1956, 97 \$106e, states: »Eine spezielle Anwendung des instrumentalen $ב$ ist die zur Angabe des Preises als des Kaufmittels und von daher auch des Kaufzieles «. Among the instances that fall under this category (of what we call beth pretii) he also mentions Gen 9,6 (the others being Gen 47,17; Hos 3,2; Isa 7,23; II Sam 23,17; Gen 29,20; Isa 40,2; Jer 42,20).

2 The following list comes relatively close to the one found in BerRabba and bSanh 57b; cf. J. Lust, ’For Man Shall His Blood Be Shed - Gen 9:6 in Hebrew and in Greek, in: G. J. Norton and St. Pisano (eds.), Tradition of the Text, 1991, 91-102, 96.

ZAW 122. Bd., S. 81-89

(C) Walter de Gruyter 2010 
man «, that is, before witnesses. The second option is to interpret באדם as another type of location that gives more information about the specific way in which the victim is killed, namely in a way that does not imply the outward shedding of blood, for instance by suffocating; it may also refer to the murder of an embryo. ${ }^{3}$ The third option is to understand באדם as an indication of means or instrument, that is, »through « or »by « man, so that the whole line reads: » Whoever sheds the blood of man by man, that is, by another man serving as his instrument, his blood shall be shed «.

c) The last word of the line, שפרי', can in principle be understood in two ways; either as a verb expressing an indicative mood, »it will be shed «, or as a verb expressing a volitive mood, »it shall be shed «.

There are in fact supporters of all the given alternatives with respect to all three questions - not quite surprisingly, since they are all possible from a purely grammatical point of view. However, there is a majority view in traditional Christian exegesis which interprets the line as follows: "Whoever sheds the blood of man, by man shall his blood be shed «.

This means that with respect to the division of the elements of the line, the dividing line is drawn after the first ("person «) and not after the second; the preposition beth that goes with the second אדם ("person «) is understood as a beth causae; and ישפך" is understood to represent a volitive $\operatorname{mood}$ (»shall be shed «).

If one consults the ancient versions, it turns out that their understanding of the colon differs considerably, with support for all of the presented solutions found in one text or another.

In the remainder of this article, we shall first present a short investigation of the first problem (syntactic structure of Gen 9,6a) and then discuss in some depth the second of the three problems (grammatical function of the preposition beth) and try to offer a solution based on linguistic observations. ${ }^{4}$

\section{Determining the Syntactic Structure of Gen 9,6a}

There are strong reasons that support the view that the syntactic structure of the line has the pattern שפך דם האדם // באדם דמו ישפך.

Only this division of the colon provides a perfect chiastic structure; it is more elegant and more orderly than its alternatives, and should therefore be preferred. This view is supported by the fact that the interpretations resulting from the linking of באדם to the first half of the line mentioned above (1. shedding of the blood of a person »before witnesses ", or 2. "in the person «, or 3. »through other human agents «) seem forced and especially in the second case overly specialised, providing a technical specification that is not warranted by the context. In all three cases, one could ask »Is it really only in the case that the bloodshed is committed באדם that the perpetrator's blood has to be or will be shed? "In all three cases, such an assumption would not stand to reason. It does not make much sense to claim that the murderer's blood must be or will be shed 1 . only if the blood was shed before witnesses, or 2. only if the blood was shed without the blood being seen, or 3. only if the blood was shed indirectly through another human agent.

3 Normally understood as occurring in the context of an abortion.

4 I hope to present a more elaborated study on Gen 9,6a dealing with all three problems and taking into account also arguments derived from observations concerning the literary context of the colon in the near future. 


\section{Determining the Grammatical Function of the Preposition Beth}

Having settled the first question, we are equipped to some degree to address the second question, though this remains a difficult topic.

By way of introduction, we first have to redefine the alternatives that present themselves. Whereas one of the alternatives, the beth pretii, does not need further explanation, the second alternative, which is often called an »instrumental beth «, 5 does. The category of beth instrumenti is closely related to beth causae, because in both cases we are dealing with the notion of agency. The differences lie merely in the question of how direct this agency is and whether it is an ultimate agent. ${ }^{6}$ Therefore, it is not only the narrower concept of beth intrumenti that has to be compared with beth pretii as different ways of understanding the preposition in Gen 9,6a, but in fact the broader function of the preposition beth marking agency, which is found both with beth instrumenti and beth causae. Therefore, the alternatives are either beth pretii, on the one hand, or beth instrumenti or beth causae, on the other hand.

\subsection{General Grammatical Characteristics of Instrumental Beth and Beth Pretii}

Generally the use of beth instrumenti and to some extent also the use of beth causae are much more widespread than that of beth pretii. ${ }^{7}$

More specifically, there are dozens of occurrences of beth instrumenti and beth causae in relation to a verb in the niph'al as in Gen 9,6, with the preposition beth marking the agent of the action described with a verb appearing in the niph'al conjugation. ${ }^{8}$ In some -

5 See, e.g., Lust, »For Man Shall His Blood Be Shed «, 92.

6 See E. Jenni, Die hebräischen Präpositionen Band 1: Die Präposition Beth, 1992, 100-102.

7 See Jenni, Die Präposition Beth, 119.151. According to his count, beth instrumenti is attested about five times more frequently than beth pretii. If the attestations of beth causae, which is semantically closely related to beth instrumenti, are also counted, the balance is leaning even more to beth instrumenti / causae, with a frequency of over six times higher than the one of beth pretii (cf. Jenni, Die Präposition Beth, 100-118).

8 See, e.g., Gen 19,15; 41,36; Ex 29,43; Lev 11,43; 18,24; 26,23.39; Deut 7,25; 21,3; Jos 7,15; Jud 16,6.10.13; Isa 5,16; 47,13; 50,10; Jer 51,6; Ez 17,21; Ps 21,8; 59,13; 90 ,7; Prov 5,22; Thr 4,14; 5,12; Ezr 9,7 (see also below 3.4.).

According to Gesenius / Kautzsch, Hebräische Grammatik, $406 \mathrm{f}$. $\$ 121 \mathrm{f}$, »die wirkende Ursache « is attached to a passive verb normally with the preposition lamed, in a few cases with the preposition min. There are also cases where the preposition beth is used, called beth instrumenti, "überall zur Einführung persönlicher Urheber« (op. cit., 407).

According to Joüon / Muraoka, A Grammar of Biblical Hebrew, Vol. II, 482-484 $\$ 132$ $\mathrm{c}-\mathrm{f}$, prepositions with a verb in the passive voice can be used to indicate the author of the action; it is the prepositions min, beth, and lamed that are found in this role, with various nuances.

According to Waltke / O'Connor, An Introduction to Biblical Hebrew Syntax, 385 $\$ 23.2 .2 \mathrm{f}$, in the complete passive, the agent may be indicated by a prepositional phrase with the prepositions beth or lamed. They add that the preposition beth is in fact more common in this grammatical function. The means or instrument of the action may be given after beth or min. 
though admittedly rare - cases we find the preposition beth attached to personal agents in the function of an instrument (or rather: cause) as in Gen 9,6. This is the case in Deut 33,29 and Isa 45,17, where the name of the God of Israel, YHWH, grammatically functions as the entity referred to by the preposition beth. A similar case is Hos 12,14, where it is the prophet »through whom « Israel was protected. In Ps 69,7, the psalmist prays that those who seek God may not be confounded ' ב, »through me", that is, through the psalmist himself. Another case with the preposition beth being affixed with a suffix that refers to a personal entity can be found in Ez 22,16, which says that Jerusalem will be desecrated by herself before the eyes of the nations.

On the other hand, there are no instances where the preposition beth in its grammatical role as a beth pretii is bound to a person (אדם ["person«], אישה ["man«], [»woman «], and so on; PN), though there are combinations with נפדפ (traditionally rendered as "soul «), and this comes of course quite close to the grammatical category "person «. ${ }^{9}$ Since semantically נפש is so close to the concept "person ", and since attestations of beth pretii in combination with נפש are relatively frequent, ${ }^{10}$ within this part of the syntactical comparison of beth causae and beth pretii the balace remains relatively equal.

Ernst Jenni lists 36 cases where verbs denoting buying and selling are used in the passive and reflexive voice with the preposition beth in its function as a beth pretii. ${ }^{11}$ In all these cases, the preposition beth is attached to an abstract noun or an indication of the amount being referred to. The only possible exception - besides Gen 9,6a - is I Sam 29,4b. In this case, the "heads of these men " are clearly used as a kind of de-personalized moneylike entity by which David could win the favour of the Philistines' enemy. This is not to deny that in fact there is a certain closeness to the use of אדם in the second hemicolon of Gen 9,6a. However, the closeness would be more poignant if in Gen 9,6 the preposition was attached to אדם אדם instead since in this case it would also be a noun designating a part of the person and not the person itself which is referred to.

\subsection{Syntactical Parallels Supporting a Beth Causae Interpretation}

The phrase באדם is attested 24 times in addition to Gen 9,6. In none of these instances do we find a beth pretii; however, in one we do find an attestation of a beth causae (Prov 28,2). ${ }^{12}$ In Koh 8,9 we even have the sequence האדם באדם. However, it does not help to clarify the issue, because באדם is directly dependent on the verb (»rule«) with the preposition beth marking the social relation.

9 In addition to נפש, there are also combinations with דם and several parts of the human body (see, e.g., Deut 19,21; II Sam 3,27; Ps 30,10). In one case, it is the god Ba al whom the preposition beth in its function as a beth pretii is attached to (Jer 23,27).

10 Deut 19,21; II Sam 14,7; 23,17; I Reg 2,23; Jer 17,21; 42,20; Jon 1,14; Prov 7,23; Thr 5,9; I Chr 11,19.

11 See Jenni, Die Präposition Beth, 153-155. In a later study, Jenni aligns שפך with the verbs "give / take " and "sell / buy « that are often used with a beth pretii, claiming that שפך is also »dreiwertig " (according to the valence system expounded by P. von Polenz; see Ernst Jenni, Studien zur Sprachwelt des Alten Testaments, 1997, 183). However, it can be disputed whether "shed « really requires two obligatory semantic slots in addition to the information about the agent.

12 Pace A. Ernst, »Wer Menschenblut vergießt ...«, ZAW 102 (1990), $252 \mathrm{f}$. 
If we look at the structure of the whole line, with the three critical elements: participle - preposition beth - and niph'al imperfect, in this sequence, we find two sentences that come particularly close to Gen 9,6a.

1. The first is Isa 65,16 :

\section{אשר המתברך בארץ יתברך באלהי אמן והנשבע בארץ ישבע באלהי אמן}

»Because he who is blessed in the earth shall be blessed by the God of truth; and he who swears in the earth Shall swear by the God of truth."

In addition to the sequence of the three critical elements mentioned above, Isa 65,16 is parallel to Gen 9,6 in a further respect: The second part of the verse is a subordinate clause

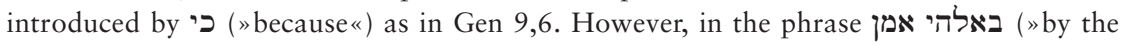
God of truth «) the preposition beth is neither a beth pretii nor a beth instrumenti or causae, so there is no light being shed on our question.

2. The second case with a structure parallel to that in Gen 9,6a is Koh 10,9:

\section{מסיע אבנים יעצב בהם בוקע עצים יסכן בם}

»He who quarries stones may be hurt by them, and he who splits logs may be endangered by them. «

Here, we find two attestations of beth causae in a sentence that comes syntactically close to the one found in Gen 9,6a.

In addition to the two texts just mentioned, there are a number of other passages that show some syntactical resemblance with Gen 9,6a:

1. The first case is Koh 7,26. At the very end of the line, we find again the three critical elements participle - niph'al imperfect - preposition beth, though the sequence of these elements is not exactly the same as in Gen 9,6a:

וחוטא ילכד בה

»but the sinner will be captured by her (i.e., the woman) «.

This hemicolon is very close to Gen 9,6 not only by the attestation of the three distinctive elements particple, niph'al imperfect, and preposition beth, but also by the fact that the preposition beth is attached to a personal entity. What is important here is that the beth used in this case is a beth causae, not a beth pretii.

2. A relatively similar syntactical structure is also found in the second part of Num 35,11, combined with a close semantic relation to Gen 9,6a:

ונס שמה רצח מכה־נפש בשגגה

"... that the manslayer who has killed any person unintentionally may flee there «. The last phrase contains three elements that are parallel to Gen 9,6a: a participle denoting "killing " (in this case, two such participles) - a noun standing in the position of the direct object undergoing the act of killing - the preposition beth. Though not being a beth instrumenti or beth causae, the function of the preposition beth in Num 35,11 probably comes somewhat closer to these categories than to the category of beth pretii, as the possible translation by »through « or »by « (»through / by man « in Gen 9,6a; »through ignorance« / »by error « in Num 35,11) might suggest.

3. Within the same chapter, we find another verse (Num 35,33) that bears close resemblance with Gen 9,6:

ולא־תחניפו את־הארץ אשר אתם בה כי הדם הוא יחניף את־ה פיאריץ

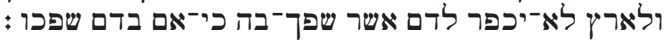

"So you shall not pollute the land in which you are; for blood pollutes the land and no expiation can be made for the land for the blood that is shed on it, except by the blood of him who shed it." 
In this verse, we encounter at least three elements that are in common with Gen 9,6a: blood which is somehow shed; the preposition beth in an instrumental / causal use; ${ }^{13}$ the occurrence of the the verb שפך ("shed «) both in an active and a passive voice. In addition, there is a kind of wordplay that consists in the recurrent combination of the noun אר (»land «) and the verb חנים (מiph'il, »pollute «) that resembles the playful double combination of the nouns דם (»blood ("), שפד (»shed «) in Gen 9,6. These remarkable syntactic parallels are matched by a concomitant overlap in contents: the blood of a person who has shed the blood of another person must be shed, as the only way by which the land can be redeemed. The strong parellelism in the message of both verses again supports the beth causae interpretation in Gen 9,6, as well as a volitive understanding of שפי', since the context of Num 35 clearly speaks of the death penalty carried out by a human agent.

Evaluating the observations adduced so far, the scales are clearly more on the beth instrumenti / beth causae side than on the beth pretii side. This tendency becomes even more accentuated if we take into consideration a sentence found in the New Testament that comes surprisingly close to Gen 9,6a, both with regard to structure and to contents (Matth 26,52b): »for all those who take up the sword shall perish by the sword «. If we were to translate this saying into Hebrew, a rendering of »by « with a beth instrumenti would be a very fitting possibility: כל האוחזים בחרב בחרב יאבדו.

\subsection{Syntactical Parallels Supporting a Beth Pretii Interpretation}

Those authors supporting a beth pretii interpretation point especially to II Sam 3,27 as a parallel to Gen 9,6a. ${ }^{14}$ The verse reads:

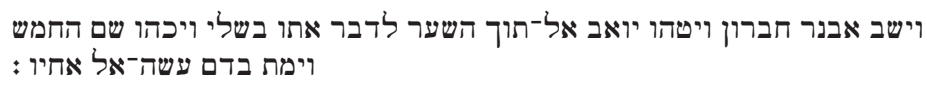

"So when Abner returned to Hebron, Joab took him aside into the middle of the gate to speak with him privately, and there he struck him in the belly so that he died on account of the blood of Asahel his brother."

It is clear that there are points of contact between the two verses that catch the eye: the theme of murder, the noun "blood «, and the preposition beth related to them. However, the differences between the two verses cannot be overlooked: There is no niph'al or any other conjugation expressing a passive voice involved in II Sam 3,27; the preposition beth is not attached to a personal agent; and there is no sequence of participial construction followed by a finite verb in the imperfect. Therefore, this sentence, though thematically related to Gen 9,6 , is syntactically quite remote and cannot be used as a means to clarify the grammatical category of the preposition beth in Gen 9,6a.

The other text frequently referred to by the supporters of a beth pretii interpretation is Deut 19,21.15 The verse reads:

\section{ולא תחום עיגך נפש בנפש עין בעין שן בשן יד ביד רגל ברגל :}

"Thus you shall not show pity: life for life, eye for eye, tooth for tooth, hand for hand, foot for foot «.

13 The preposition beth attached to דם דast be classified more precisely as a beth instrumenti.

14 See Ernst, »Wer Menschenblut vergießt ...«, 253.

15 See Ernst, »Wer Menschenblut vergießt ...«, 253; Lust, »For Man Shall His Blood Be Shed «, 94.96 . 
It is approximately the same reservations that must be made with respect to the comparison of this verse with Gen 9,6 as those adduced with regard to II Sam 3,27. As opposed to II Sam 3,27, one might argue that a passive construction is at least implied in the present case. However, this interpretation is not compelling. Moreover, the construction of Deut 19,21 is further away from Gen 9,6 by neither speaking of אדם ("person«) nor of דם (»blood «).

In fact, the link between Gen 9,6 and II Sam 3,27 and Deut 19,21 would be closer if

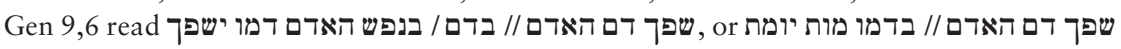

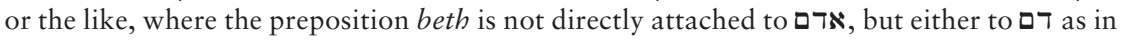
II Sam 3,27 or to נפש as in Deut 19,21.

Among the attestations of the beth pretii, besides the two cases just mentioned it, is especially I Sam 29,4b, a text already hinted at above, which comes relatively close to Gen 9,6a. The text reads as follows:

\section{ובמה יתרצה זה אל-אדניו הלוא בראשי האנשים ההם}

»For with what could this man make himself acceptable to his lord? Would it not be with the heads of these men? «

Again, it is the same kind of reservations already mentioned with respect to II Sam 3,27 and Deut 19,21, that apply if one tries to compare this verse with Gen 9,6a: no passive construction involved, the preposition beth not attached to a personal agent, and no sequence containing the elements participle - preposition beth - niph'al imperfect.

If syntactical observations concerning the use of beth causae and beth pretii thus rather clearly tip the balance on the side of the former alternative, why did the author of the line not make things even clearer by following one of the two alternative solutions: 1 . by forming a sentence that would avoid the niph'al construction and give a direct order to the addressees to claim the blood of a murderer, for example in a sentence like / שפך דם האדם ביד במו שפך instead of simple beth?

These questions will be addressed in the next two paragraphs.

\subsection{The Function of the Niph'al Conjugation}

As to the use or avoidance of a niph'al construction: The niph'al functions normally to hide the author of an action, so the use of a niph'al construction at first sight squares badly with an interpretation of באדם as an indication of the agent behind However, this function of the niph'al should not be overstressed, since there are several cases where the preposition beth is used to indicate the personal agent of an action expressed in the niph'al; avoidance of the combination of niph'al and indication of the author of the action is not an absolute grammatical law, but a rule that allows exceptions. ${ }^{16}$ We have already encountered several instances above. To those, we may add the following: Gen 19,15; Ex 29,43; Lev 11,43; 18,24; 26,23.39; Deut 7,25; Jos 7,15; Jud 16,6.10.13; Isa 5,16; 47,13; 50,10; Jer 51,6; Ez 17,21; Ps 21,8; 59,13; 90,7; Prov 5,22; Thr 4,14; 5,12; Ezr 9,7, and many more.

In addition, the combination of niph'al and an explicit indication of a personal agent by the preposition beth may serve to hint at a double agency: an ultimate, somehow hidden divine agent, indirectly pointed at by the passive voice, and a direct human agent who is in fact executing his action on behalf of the divine commissioner. Lastly, it is likely that the

16 See again Joüon / Muraoka, A Grammar of Biblical Hebrew, Vol. II, 482f. $\mathbb{S ~ 1 3 2 c ;}$ Waltke / O’Connor, An Introduction to Biblical Hebrew Syntax, 385 \$23.2.2f. 
choice of the niph'al was also influenced by the fact that it is only by the באדם - niph'alconstruction that the exact parallelism of the two halves of the line could be attained.

\subsection{Alternatives to the Preposition Beth: תחת / ביד}

As to the alternative ביד (»through / by the hand of «), the question why it was not chosen in Gen 9,6a must be given due weight in light of the fact that in the preceding verse the phrase מיד in the meaning »from the hand of « appears. Against this background, the use of ביד would have been an adequate stylistic means of connecting the two verses. In response, one could argue that the author of the passage found the saying as it stands and did not want to change it. But this does of course not answer the question on a deeper level, for now we are simply left with the further question why the original author of the saying chose simple beth rather than ביד.

I would suggest that there may be an answer to this question, or rather two answers.

First: By choosing simple beth, the almost perfect chiastic parallelism of the line could better be preserved; ביד would be heavier than simple beth and thereby lead to the impression that the balance between the two sides of the line is somewhat disturbed by the insertion of an additional element at the beginning of the second half.

Second, and more important: We may assume that we are dealing here with a case of deliberate ambiguity: Although grammatically the beth instrumenti / beth causae interpretation has more weight, as we have seen so far, the avoidance of ביד gives room for a secondary interpretation along the beth pretii line as well - and this is perhaps exactly what the author wanted to do.

This argument can also be used for the niph'al problem: Only by using the niph'al of באדם was in combination with to introduce the double meaning of »through man « and »for the value of man «.

We must also note that there would have been a possibility to replace the preposition beth with תחת (»instead of «) to give unequivocal expression to the idea of compensation by the exact value of the person who was killed, as we find it in the phrase נפש תחת נפש ("life for life «) in Ex 21,23 and Lev 24,18. In this case, the concept present in beth pretii would have been expressed without ambiguity. ${ }^{17}$ But again, this has not been done, most probably because the writer did not want to deliver such a clear, one-sided message.

\section{Conclusion}

Taking into consideration a variety of different indications, it emerges that the elements supporting an interpretation of the syntactic structure of Gen 9,6a in the sense of the strictly

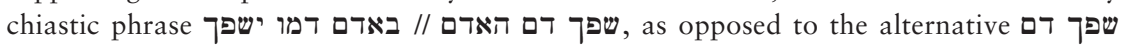
שאים, clearly dominate. On the other hand, the balance regarding the specific issue of the interpretation of the preposition beth in באדם is more equal, with some dominance given to the beth causae interpretation as against the beth pretii interpretation. This near equilibrium is underlined by those elements that directly favour a double understanding of the preposition. It becomes clear, then, that the linguistic categories of causation and value that must be distinguished in most Western languages could effectively be combined in biblical Hebrew in the use of the preposition beth. The proposed interpre-

17 The semantic equivalence of נפש בנפש a נפש תחת נפש is shown by a comparison of Ex 21,23 and Lev 24,18 on the one hand and Deut 19,21 on the other. 
tation of Gen 9,6a can be summarized in the following free rendering of the colon: "Whoever sheds the blood of man, by man and for the value of man shall his blood be shed «.

Genesis 9,6a, mostly translated as "Whoever sheds the blood of man, by man shall his blood be shed «, has often been understood as a divine ordinance prescribing the death penalty for (intentional) murderers. Others have proposed to interpret the preposition beth not as a beth causae, but as a beth pretii. This article seeks to demonstrate that the linguistic categories of causation and value that must be distinguished in most Western languages can effectively be combined in biblical Hebrew in the use of the preposition beth.

Gen 9,6a, le plus souvent traduit par: »Quiverse le sang de l'homme, par l'homme son sang sera versé «, est habituellement compris comme un précepte divin, celui de la peine de mort pour tout homicide (volontaire). D'autres ont proposé d'interpréter la préposition bèth non comme un bèth causae, mais un bèth pretii. La présente étude vise à démontrer que les catégories de la causalité et de la valeur, qui doivent être distinguées dans la plupart des langues occidentales, sont en fait liées dans l'usage de la préposition bèth en hébreu biblique.

Genesis 9,6a, meist übersetzt mit »Wer Menschenblut vergießt, dessen Blut soll durch Menschen vergossen werden ", wurde oft als ein Auftrag Gottes zur Todesstrafe an (vorsätzlichen) Mördern verstanden. Andere haben vorgeschlagen, die Präposition beth nicht als beth causae, sondern als beth pretii zu deuten. Die vorliegende Studie versucht aufzuweisen, dass die sprachlichen Kategorien von Kausalität und Wert, die in den meisten westlichen Sprachen unterschieden werden müssen, im biblischen Hebräisch im Gebrauch der Präposition beth effektiv verbunden werden können. 